\title{
Changes in the spatial and temporal pattern of natural forest cover on Hainan Island from the 1950s to the 2010s : implications for natural forest conservation and management
}

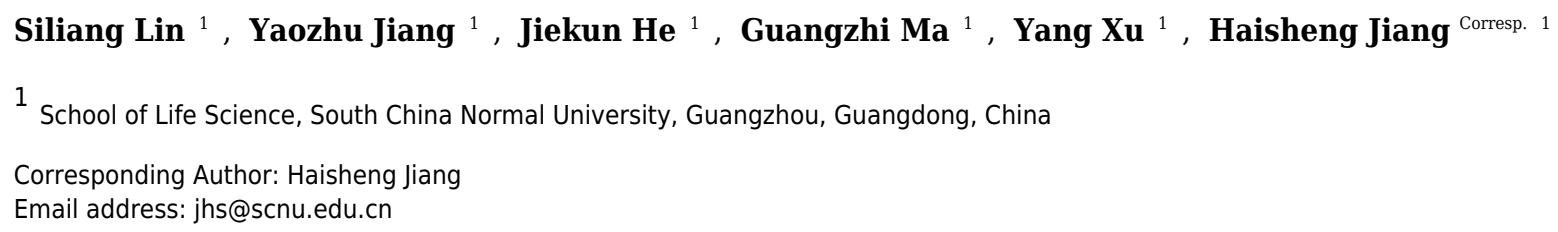

The study of the past, present, and future state and dynamics of the tropical natural forest cover (NFC) might help to better understand the pattern of deforestation and fragmentation as well as the influence of social and natural processes. The obtained information will support the development of effective conservation policies and strategies. In the present study, we used historical data of the road network, topography, and climatic productivity to reconstruct NFC maps of Hainan Island, China, from the 1950s to the 2010s, using the random forest algorithm. We investigated the spatial and temporal patterns of NFC change from the 1950s to the 2010 s and found that it was highly dynamic in both space and time. Our data showed that grid cells with low NFC were more vulnerable to NFC decrease, suggesting that conservation actions regarding natural forests need to focus on regions with low NFC and high ecological value. We also identified the hot-spots of NFC change, which provides insights into the dynamic changes of natural forests over time. 
1 Changes in the spatial and temporal pattern of natural forest cover

2 on Hainan Island from the 1950s to the 2010s: implications for 3 natural forest conservation and management

5 Siliang Lin ${ }^{a \dagger}$, Yaozhu Jiang ${ }^{a \dagger}$, Jiekun $\mathrm{He}^{\mathrm{a}}$, Guangzhi Ma a ,Yang $\mathrm{Xu}^{\text {a }}$, Haisheng Jiang ${ }^{\text {a* }}$

6 a School of Life Sciences, South China Normal University, Guangzhou, Guangdong 510631, 7 China

$8 \uparrow$ These authors contributed equally to this study.

10 * Correspondence authors: Haisheng Jiang

11 School of Life Science, South China Normal University, Guangzhou, Guangdong 510631, China.

13 Telephone: +8615989147874

14 E-mail: jhs@scnu.edu.cn 


\section{Abstract}

16 The study of the past, present, and future state and dynamics of the tropical natural forest cover

17 (NFC) might help to better understand the pattern of deforestation and fragmentation as well as

18 the influence of social and natural processes. The obtained information will support the

19 development of effective conservation policies and strategies. In the present study, we used

20 historical data of the road network, topography, and climatic productivity to reconstruct NFC

21 maps of Hainan Island, China, from the 1950s to the 2010s, using the random forest algorithm.

22 We investigated the spatial and temporal patterns of NFC change from the 1950 s to the 2010 s and found that it was highly dynamic in both space and time. Our data showed that grid cells with low NFC were more vulnerable to NFC decrease, suggesting that conservation actions regarding natural forests need to focus on regions with low NFC and high ecological value. We also identified the hot-spots of NFC change, which provides insights into the dynamic changes of natural forests over time. 


\section{INTRODUCTION}

32 Human activity is the dominant cause of contemporary environmental change worldwide

33 (Lewis \& Maslin, 2015). Land use by humans is a major component of the long-term anthropogenic global changes that have defined the "Anthropocene" as a new epoch of geologic time (Ellis et al., 2013; Dirzo et al., 2014; Lewis \& Maslin, 2015). The study of land use and land cover change was initially dominated by monitoring and modelling of the ecological impacts of major land cover changes, such as deforestation and desertification, on the natural system (Lambin \& Geist, 2006). However, research of land cover change has now become more integrative, focusing on both the drivers and impacts of land change, including a wider range of interacting processes. Understanding the drivers, state, trends and impacts of different land cover change in combination with the social and natural processes might help to reveal the effects of land system changes on the socio-ecological system and consequently develop effective conservation strategies.

environment, since these forest harbour exceptional biodiversity, providing important ecosystem services that support the livelihood of local communities (Myers et al., 2000; Sodhi et al., 2006;

Page, Rieley \& Banks, 2011; Arima, 2016). The study of the past, present, and future state and dynamics of the tropical natural forest cover (NFC) changes might help to better understand the manner of deforestation and fragmentation as well as the influence of social and natural processes. The obtained information will support the development of effective conservation policies and strategies, especially in areas with rapid forest decline (Romijn et al., 2015). The 
52 first comprehensive assessment of global forest resources was reported by Zon \& Sparhawk 53 (1923), the Food and Agriculture Organization (FAO) of the United Nations has carries out

regular assessments (Forest Resources Assessments; FRA) at intervals of five or ten years since 1948 (MacDicken, 2015). Although the FRA data are only partially accurate (Grainger, 2008), they shed light on NFC changes at a global scale (MacDicken, 2015). though not at a local scale, mainly because the mechanisms of NFC changes are more complicated than those reported in previous studies (Lambin, Geist \& Lepers, 2003). Remote sensing by satellites has been used to tracking NFC since 1972 (Grainger, 2008). Hansen et al. (2013) developed a dataset of highresolution global maps and assessed forest cover change from 2000 to 2012 using satellite data with a spatial resolution of $30 \mathrm{~m}$. These results depict a globally consistent and locally relevant record of forest change. However, little is known about the long-term historical distribution of NFC prior to the 1970s (Liu \& Tian, 2010). Overall, it is essential to assess the historical distribution of NFC at a specific spatial scale (Miao et al., 2013) in order to explore the underlying mechanisms (Goldewijk, 2001; Goldewijk et al., 2011) and create more effective conservation policies.

Previous studies used biophysical (e.g. topography and climate) and socio-economic data (e.g. population density, road networks, migration, urban extension, and gross domestic product) to reconstruct the long-term historical distribution of NFC (Millington, Perry \& RomeroCalcerrada, 2007; Arima et al., 2008; Miao et al., 2013; He, Li \& Zhang, 2014). However, these variables are only valid in regions with abundant historical data. Of the variables, roads have long been considered an important driver of deforestation in many tropical countries, because of 
their high availability and strong correlation with NFC (Arima et al., 2005; Arima et al., 2008;

Gaveau et al., 2009; Freitas, Hawbaker \& Metzger, 2010; Cai, Wu \& Cheng, 2013; Walker et al. 2013; Li et al., 2014; Arima et al., 2016; Hu et al., 2016). Multiple studies have focused on the effect of roads on NFC, but only a few of them have used the temporal and spatial dynamics of road networks for studying the distribution of NFC (Perz et al., 2007; Perz et al., 2008; Ahmed et al., 2013; Newman, Mclaren \& Wilson, 2014).

Hainan is the largest island in the Indo-Burma biodiversity hotspot and harbours high levels of biological endemism (Myers et al., 2000). Natural forest initially covered almost the entire island, but NFC has now decreased to less than one quarter, mainly in the central mountainous area of the island, owing to the intensive exploitation and deforestation since the 1950s (Lin et al., 2015). Although the NFC changes in Hainan have been previously reported, limited information is available regarding the distribution of NFC over time, which is important to better understand the dynamics of wildlife communities (Brook et al., 2006), especially of some endangered species (e.g. Hainan Gibbon; Xu et al., in press). The deforestation of Hainan Island has led to a series of grave ecological consequences (e.g. large floods, landslides, and drought) that threatened the local communities and decreased the overall environmental quality (Wang et al., 2014). Thus, understanding the spatial and temporal dynamics of NFC is crucial to evaluate the environmental quality and restore forest ecosystems that important services to the local residents. Here, we used historical road maps and environmental variables to simulate and document the temporal and spatial dynamics of NFC on Hainan from the 1950s to the 2010s. First, we fitted a random forest (RF) model to simulate the distribution of NFC with road-related and 
94

95

96

97

98

99

100

101

102

103

104

105

106

107

108

109

110

111

112

113

114

environmental variables in 1975,1995 , and 2012. Next, we used the random forest model to reconstruct the NFC at a 20 -years intervals from the 1950s to the 2010s. Based on our data, we aimed to: (1) explore the effect of the road network on NFC changes and (2) identify changes in the distribution of NFC from the 1950s to the 2010s.

\section{MATERIAL and METHODS}

\section{Study area}

This study was carried out on Hainan Island, an area of approximately $33,900 \mathrm{~km}^{2}$ located in south China (Fig. 1). The island has a central mountainous region with a maximum elevation of $1,867 \mathrm{~m}$ (Fig. 1) and is flat in the northern and coastal regions. The climate is tropical with warm and humid weather. The average annual temperature ranges from $16^{\circ} \mathrm{C}$ in January to $27.5^{\circ} \mathrm{C}$ in July. The annual rainfall is over $1,600 \mathrm{~mm}$ (Francisco-Ortega et al., 2010) and unevenly distributed both between the rainy and dry season and across the island. Rainfall mainly occurs in eastern Hainan Island (Wenchang, Qionghai, Wanning, Lingshui, and Sanya Counties) due to typhoons from the Pacific Ocean. The western part of the island is characterized as dry, while the eastern part is humid (Xu et al., in press).

Prior to 1950s, the forest area on Hainan Island was largely natural, since the number ofcoconut and rubber plantations was limited island (Chen, 1948), whereas the non-forest area was mainly farmland. The natural forest area decreased considerably owing to logging for timber, rubber plantations, and residential expansion, with NFC reached a minimum in the 1980s. In response to this dramatic NFC loss, the Hainan Provincial Government established a natural 
115 forest logging ban in 1994 (Standing Committee of Hainan Provincial People 's Congress, 1993;

116 Zhang, Uusivuori \& Kuuluvainen, 2000).

\section{Distribution of natural forest}

118 In this study, arboreal forest, shrub land, and open woodland were considered as natural

119 forest based on the standards of the National Forest Inventory of China (SFA PRC, 2004). The

120 distribution of natural forest in 1975 was obtained from 93 topographical maps of Hainan Island

121 and digitised using ArcInfo 9.3. (ESRI, 2008; see Appendix 1 for more details). These maps

122 incorporated different types of land uses and outlined the distribution of arboreal forest, shrub

123 land, and open woodland. The distribution of natural forest in 1995 and 2012 was reproduced

124 from maps of the $5^{\text {th }}$ and the $8^{\text {th }}$ National Forest Resources Inventory of China

125 (http://www.forestry.gov.cn/gjslzyqc.html). Three datasets of the historical natural forest

126 distribution were primarily produced by aerial photography and validated by field observations.

127 Field investigation data of 1997/1998 and 2012/2013 (Xu et al., in press) were used to estimate

128 the accuracy of natural forest distribution in 1995 and 2012 (Fig. S1). To enhance data

129 consistency, the NFC distribution in the 1970s, 1990s and 2010s was combined using the

130 'Simplify polygon' function in ArcInfo 9.3. (ESRI, 2008).

131 We established a $5 \times 5 \mathrm{~km}$ grid cell system for model simulations. First, Hainan Island was

132 divided into $5 \times 5 \mathrm{~km}$ grid cells, and those with a land area less than $50 \%$ were excluded to

133 minimise the bias of low NFC. A total of 1360 grid cells were used for further analysis. Next, we

134 overlaid the polygons of natural forest in 1975, 1995 and 2012 with the grid cells, and the

135 proportion of natural forest was considered as the NFC of grid cell. The obtained NFC datasets 
136

137

138

139

140

141

142

143

144

145

146

147

148

149

150

151

152

153

154

155

156

were used as a response variable in model simulations.

\section{Variables correlated with NFC}

We investigated three main categories of variables with a potentially high correlation with

NFC: (1) topography, such as slope (SLO, ${ }^{\circ}$ ) and elevation (ELE, m), which indicate difficulty in accessibility and historical exploitation (Teixeira et al., 2009); (2) climatic potential productivity $\left(\mathrm{CPP}, \mathrm{Kg} \cdot \mathrm{hm}^{-2} \cdot \mathrm{a}^{-1}\right)$, which indicates the potential of forest loss due to crop farming (Pongratz et al., 2008); and (3) road network, which indicates the scale and intensity of socio-economic impact on NFC (Arima et al., 2005; Walker et al. 2013; van der Ree, Smith \& Grilo, 2015; Arima et al., 2016).

Digital elevation data (approximately $90 \times 90 \mathrm{~m}$ resolution) were obtained from the Consortium for Spatial Information (http://www.cgiar-csi.org/data/srtm-90m-digital-elevationdatabase-v4-1). The slope map was created based on changes in elevation between adjacent pixels of the digital elevation data. Data on the climatic potential productivity (approximately $1 \times$ $1 \mathrm{~km}$ resolution) were obtained from the National Earth System Science Data Sharing Infrastructure (http://www.geodata.cn/index.html). The SLO, ELE, and CPP of each grid cell were calculated by averaging all cells $(1 \times 1 \mathrm{~km}$ or $90 \times 90 \mathrm{~m})$ such that their centroid fell within each $5 \times 5 \mathrm{~km}$ grid cell.

Historical data of the road network were obtained from maps and digital databases published prior to 2013 (Table S2). Maps were digitised using ArcInfo 9.3.(ESRI, 2008) and assigned to a 20-year interval. Due to differences in the mapping scale of traffic maps, the Rural road was designated as the lowest level road, whereas Expressway, Highway, Simply-built 
157 highway, and Cart road were designated as roads with relatively higher levels (Table S2). Based

158 on the function and surface material of various roads, we classified these roads into two classes

159 in the 1950s, 1970s, 1990s and 2010s: main road (Expressway, Highway, and Simply-built

160 highway) and secondary road (Cart road and Rural road).

161 Four road-related variables: including the sum of road length (SRL, $\mathrm{km} \mathrm{km}^{-2}$ ), the distance

162 from the grid cell centroid to the nearest road (DNR, km), the number of nodes of road network

$163\left(\mathrm{NON}\right.$, ea $\mathrm{km}^{-2}$ ), and the mean node degree (MND, ea km $\mathrm{km}^{-2}$; the mean number of roads connected

164 to each node), were calculated in each grid (Table S3) to represent the density and configuration

165 of the road network in the 1950s, 1970s, 1990s, and 2010s.

\section{Reconstruction of the historical NFC from the 1950s to the 2010s}

Prior to the reconstruction of the historical NFC, we tested the predictive performance of

four modelling techniques, including the generalized linear model (GLM), generalized additive model (GAM), artificial neural networks (ANN) model, and random forests (RF) model. We

used the normalised mean square error (NMSE) to compare the predictive performance of the

four models in simulating the NFC of each $5 \times 5 \mathrm{~km}$ grid cell (Appendix 5). NMSE is a relative

measure, estimating the overall deviation between predicted and measured values and also a unit-

less measure in the interval $[0,1]$. The modelling technique with the lowest value of NMSE has

the highest predictive performance. The RF model showed the lowest NMSE among the four

models and consequently, was used for reconstructing the historical NFC from the 1950s to the

2010s (Table S4).

The RF model (Iverson et al., 2008) is characterized by insensitivity to multicollinearity, 
steadiness across unbalanced datasets, accuracy in predicting the effects of multiple explanatory variables (Breiman, 2001; Culter et al., 2007), higher efficiency in large datasets than that of traditional machine-learning techniques, suitability in demonstrating the nonlinear effect of variables, modelling complex interactions among variables, and robustness to outliers (Li, 2013; Breiman, 2001; Culter et al., 2007). In the present study, we fitted the RF model to associate the NFC data of each grid cell with SLO, ELE, CPP, and main and secondary road networks related indicators (SRL, DNR, NON, and MND) in the 1970s, 1990s, and 2010s. Next, we used the obtained RF model to reconstruct the historical NFC of each grid cell at 20-year intervals from the 1950 s to the 2010 s, according to the topography, climate, and road network data in a specific period. We assumed that topography and climate did not change significantly over a relatively short time and therefore used the same SLO, ELE, and CPP in all the assessed time periods (1950s-2010s, 1950s-1970s, 1970s-1990s, and 1990s-2010s). The methodological sequence describing the input data, the modelling and validation approaches, and the generation of predictions is shown in the Fig.2.

Overall, we investigated the historical, temporal, and spatial dynamics of NFC on Hainan Island from the $1950 \mathrm{~s}$ to the 2010s. We first applied simple linear regression to explore the relationship between each road-related indicator and the NFC change rate of each grid cell in the four assessed time periods. We used adjusted $\mathrm{R}^{2}$ to estimate the explanatory power of each roadrelated indicator in the simple linear regression model. The variation partition was also applied to compare the effects of main roads vs. secondary roads on NFC change. Simple linear regressions with the combined effect of the four road-related indicators of main road and secondary roads 
199 200

202

203

204

205

206

207

208

209

210

211

212

213

214

215

216

217

were used to estimate the variation partition of different road types in the four assessed time periods.

All analyses were conducted in R 3.2.3 (R Development Core Team, 2016) using the 'mgcv' (Wood, 2011), 'caret' (Kuhn, 2016), 'randomForest' (Liaw \& Wiener, 2002), 'DMwR' (Torgo, 2011) packages.

\section{Hot-spots analysis}

To quantify the degree of deforestation, the Getis-Ord Gi* statistic was computed to measure the degree of spatial clustering of a local sample and its difference from the expected value using the sum of the differences between values in the local sample and the mean, and is standardized as a Z score (Scott \& Warmerdam, 2005). The Z score reveals the spatial clustering of features with either high or low values. To test the significance of the $\mathrm{Z}$ score the value within a specific confidence level were compared. Positive $\mathrm{Gi}^{*}$ values represent clusters that are greater than the mean (reforestation Hot-spots), whereas negative $\mathrm{Gi}^{*}$ values represent clusters that are lower than the mean (Deforestation Cold-spots; Getis \& Ord, 1996; Cohen et al. 2011). This statistic represents the frequency of a hotspot relative to the number of input deforested points covered the area. To identify spatial clustering patterns of NFC changes at 20 -year intervals, hotspots analysis was performed using Getis-Ord Gi* statistics (Mitchell, 2005) with the 'Hot Spot Analysis' function in ArcInfo 9.3. (ESRI, 2008).

The Getis-Ord Gi* was calculated as follows: 


$$
G_{i}^{*}=\frac{\sum_{j=1}^{n} w_{i, j} x_{j}-\bar{X} \sum_{j=1}^{n} w_{i, j}}{s \sqrt{\left[\frac{\left[n \sum_{j=1}^{n} w_{i, j}^{2}-\left(\sum_{j=1}^{n} w_{i, j}\right)^{2}\right]}{n-1}\right.}}
$$

where $x_{j}$ is the attribute value for feature $\mathrm{j}, w_{i, j}$ is the spatial weight between feature $\mathrm{i}$ and $\mathrm{j}$,

220 and $\mathrm{n}$ is equal to the total number of features. The $G_{i}^{*}$ statistics is a $\mathrm{Z}$ score and thus, no further

221 calculations are required.

\section{RESULTS}

\section{The temporal and spatial dynamics of NFC}

NFC changes at 20-year intervals from the 1950 s to the 2010 s are shown in Fig. 3. We also

calculated the total NFC to explore the temporal dynamics of NFC from the 1950 s to the 2010 s.

The trend of total NFC indicated a considerable decrease from $41.4 \%$ in the 1950 s to $24.2 \%$ in

the 2010s (Fig. 4; $\left.\mathrm{R}^{2}=0.99, p=0.004\right)$.

In the $1950 \mathrm{~s}$, most grid cells with $\mathrm{NFC}>50 \%$ were identified in the central mountainous

regions, whereas those with $\mathrm{NFC}<20 \%$ were identified in the coastal regions (Fig. 3). The grid 2010s (Fig. 3), whereas their distribution gradually shifed from the coastal regions to the mountainous regions (Fig. 3). The grid cells with NFC $>50 \%$ mainly distributed in the central and southern mountainous region, but showed a significant decrease from 544 to 286 from the 1950s to the 2010s (Fig. 3). These results revealed that that the natural forest decrease and also 
We used the slope of site-specific relationships between NFC and its change rate over time

237

239

240

241

242

243

244

245

246

247

248

249

250

251

252

253

254

255

256

to identify the dynamic change patterns of NFC. The slopes were positively correlated from the 1950 s to the 2010s., indicating that a lower NFC tended to correspond to a higher rate of NFC decrease (Fig. 5; $\mathrm{F}=122.3, p<2.2 \times 10^{-16}$ ). Assessing the pattern of NFC change rate revealed that most grid cells with low NFC change rate were distributed in the mountainous areas (Jiangfengling, Yinggeling, and Wuzhishan mountains), whereas most grid cells with high NFC change rate were distributed in the Qiongbei Platform (Fig. 5). Hot-spots analysis from the 1950s to the 2010s showed that NFC decrease mainly occurred in the platform area, whereas NFC increase occurred in the mountainous region (Fig. 6). However, NFC also increased in Wenchang County, although this area is flat and well developed. When assessed at 20-year intervals, the distribution of hot-spots with decreased NFC was observed to be shifted from the eastern regions to the western regions of Hainan Island (Fig. 6).

\section{Dynamics of road expansion}

The density and configuration of the main road network markedly changed with the time from the 1950 s to the $2010 \mathrm{~s}$. The mean SRL of main roads increased from $0.11 \mathrm{~km} \mathrm{~km}^{-2}$ in the $1950 \mathrm{~s}$ to $0.45 \mathrm{~km} \mathrm{~km}^{-2}$ in the 2010s (Table 1). The standard deviation of SRL of main roads also increased, indicating that the distribution of main roads became more heterogeneous across the grid cells. The mean DNR decreased from $0.30 \mathrm{~km}$ in the $1950 \mathrm{~s}$ to $0.04 \mathrm{~km}$ in the $2010 \mathrm{~s}$ (Table 1). The standard deviation of DNR also decreased, indicating that the spatial distribution of main roads markedly increased. The average value of NON and MND of main roads increased from the 1950 s to the 2010s (Table 1), revealing that the configuration of the road network became 
257

258

259

260

261

262

263

264

265

266

267

268

269

270

271

272

273

274

275

276

277

more complicated across the grid cells. The standard deviation of NON of main roads increased from 0.04 ea $\mathrm{km}^{-2}$ to $0.23 \mathrm{ea} \mathrm{km}^{-2}$ from the $1950 \mathrm{~s}$ to the $2010 \mathrm{~s}$, whereas the standard deviation of MND of main roads had slightly decreased from 0.05 ea $\mathrm{km}^{-2}$ to $0.04 \mathrm{ea} \mathrm{km}^{-2}$, revealing that the configuration of the main road network became more complex and the spatial pattern of main road was uneven across the grid cells.

The SRL of secondary roads increased from $0.18 \mathrm{~km} \mathrm{~km}^{-2}$ in the $1950 \mathrm{~s}$ to $0.36 \mathrm{~km} \mathrm{~km}^{-2}$ in the 1970s, but remained stable after the 1970s. The NON and MND of secondary roads also showed the same trend both clearly increase in the 1950s to $1970 \mathrm{~s}$, but remained stable after the 1970s (Table 1). The DNR of secondary roads had decreased from $0.11 \mathrm{~km}$ in the $1950 \mathrm{~s}$ to $0.05 \mathrm{~km}$ in the $1970 \mathrm{~s}$, whereas only slightly changed after the $1970 \mathrm{~s}$. The standard deviation of the four road-related indicators showed that the secondary road network markedly changed in for the 1950 s to 1970 s, but remained stable after the 1970 s (Table 1). The density and configuration of the secondary road network markedly changed from the 1950 s to 1970 s, whereas it changed only slightly after the 1970s (Table 1).

Both the main road and secondary road network obviously developed from the 1950 s to the 2010s: however, the construction processes were faster in the former than the latter. Overall, the density and configuration of the road network was higher and more complex after nearly 60 years of construction.

\section{Effects of different road expansion on NFC change}

The change of SRL of main roads explained $11.20 \%(p<0.001)$ of the variance in NFC change from the 1950 s to the 2010 s and was also the strongest indicator in the other three 
278 assessed time periods (1950s-1970s, Adjusted $\mathrm{R}^{2}=14.22 \%, p<0.001 ; 1970 \mathrm{~s}-1990 \mathrm{~s}$, Adjusted

$279 \mathrm{R}^{2}=20.73 \%, p<0.001$; and 1990s-2010s, Adjusted $\mathrm{R}^{2}=4.89 \%, p<0.001$; Table 2). In the

$2801950 \mathrm{~s}-2010 \mathrm{~s}$, the overall variation partition of main roads (Adjusted $\mathrm{R}^{2}=23.40 \% ; p<0.001$ ) in

281 the simple linear regression was much higher than the secondary roads (Adjusted $\mathrm{R}^{2}=13.30 \% ; p$

$282<0.001)$. The change of main roads also explained a higher degree of the variance than the

283 change of secondary roads in the other three assessed time periods. These results indicated that

284 the main road network had a more significant effect on deforestation than the secondary road

285 network from the 1950s to the 2010s.

286 In the $1990 \mathrm{~s}-2010 \mathrm{~s}$, the adjusted $\mathrm{R}^{2}$ of the main road network decreased from $25.2 \%$ to $5.10 \%$

287 (Table 2), whereas that of the secondary road network decreased from $8.99 \%$ to $0.12 \%$ (Table 2 ),

288 showing that the association between the road network and deforestation weakened with time.

289 However, the main road network still showed linkage stronger association with NFC change than

290 the secondary road network $(5.10 \%$ vs. $0.12 \%)$.

291

292 DISCUSSION

293 NFC reduction and fragmentation

294 Our results demonstrated that the total NFC of Hainan Island decreased significantly from

295 the 1950 s to the 2010 s (Fig. 4), and the distribution of grid cells with NFC $<20 \%$ increased in

296 the mountainous regions and thus became more vulnerable to deforestation (Fig. 5). These

297 patterns are consistent with those reported in other tropical regions, in which natural forest

298 deforestation is always accompanied by fragmentation (Pimm, 1998; Laurance et al., 1998; 
DeFries et al., 2005). Natural forest that is severely fragmented shows small patches of natural

forest that are highly vulnerable to clearing (Stickler et al., 2013; Taylor, 2013). We also

observed that the grid cells with NFC $>50 \%$ were located in areas with a high altitude and steep

slope (Fig. 3), in which mechanisation and accessibility are limited (Freitas, Hawbaker \&

Metzger, 2010; Hu et al., 2016). Most nature reserves on Hainan Island were similarly

distributed in the mountainous regions with high altitude and steep slope (Lin et al., 2015).

Although some grid cells located in some mountainous regions showed a moderately high degree

of recovery (Fig. 5), most of them with NFC $>50 \%$ was shrank and fragmented.

Natural forest fragmentation is a major issue in tropical environments, since the spatial

arrangement and geometric configuration of fragments can impair ecological processes. Six

general fragmented patterns have been recognised at the global scale in previous work (Geist \&

Lambin, 2002; Mertens \& Lambin, 1997), of which five are observed in the Amazon tropical

forest - rectangular, fishbone, radial, dendritic, and 'the stem of the rose' (Arima et al., 2005).

Road network architecture plays a critical role in shaping forest fragmentation patterns in the

Amazon (Arima et al., 2005; Soares-Filho et al. 2006; Walker et al. 2013). We also revealed that

the road network expansion explained more than $30 \%$ of natural forest deforestation and

fragmentation on Hainan Island from the 1950s to the 2010s (Table 2; Fig. 5). When the road

network was overlaid by grid cells with high NFC (Appendix 6; Fig. S2), we found that the dominant fragmented pattern of Hainan Island natural forest was radial and dendritic. Unlike the

Amazon, road construction combined the complex topography determined the pattern of natural

forest landscape on Hainan Island (Fig. 1). Thus, forest fragmentation patterns on the Hainan 
320

321

322

323

324

325

326

327

328

329

330

331

332

333

334

335

336

Island were highly affected by road construction and topography.

Our analysis showed that hot-spots with decreased NFC mainly occurred in the Qiongbei

Platform (Fig. 5), following a dynamic spatial distribution pattern from east to west, whereas

hot-spots with increase NFC occurred in Wenchang County (Fig. 5), an area that is flat and well

developed with a frequent typhoon occurrence during the summer. The local residents preserved

some small patches of natural forest around the villages and buildings, known as "geomantic

forest", as a protecting shield against the severe weather events.

\section{Effect of road network on natural forest deforestation}

Road-related indicators are not the actual drivers of NFC decrease, but they play a role in natural forest dynamics through land-use changes and deforestation (Freitas, Hawbaker \& Metzger, 2010; Newman, McLaren \& Wilson, 2014). The development of roads and road networks is strongly correlated with the economic growth and is associated with the ecological disturbance and natural forest degradation (Wilkie et al., 2000; Laurance, Goosem \& Laurance, 2009). In tropical forests, roads have a low direct effect on habitat loss, but a high indirect effect on the spatial patterns of deforestation (Fearnside, 2008), since they facilitate accessibility, resource extraction, and human activities (Selva et al., 2011; Hu et al., 2016). Our results were consistent with those of previous studies that also reported the significant effect of road networks on natural forest deforestation in tropical regions (Perz et al., 2007; Gaveau et al., 2009; Freitas, Hawbaker \& Metzger, 2010; Cai, Wu \& Cheng, 2013; Li et al., 2014; Arima et al., 2016; Hu et al., 2016). We demonstrated that road-related indicators played a substantial role in determining the deforestation of NFC in Hainan. The SRL of main roads was one of the strongest variables 
341 associated with NFC change dynamic in the four assessed time periods(Table 2). However, the

342 power of road network in explaining the NFC reduction weakened over time, in both main and

343 secondary roads, probably revealing the underlying socio-economic processes of road expansion

344 itself (Perz et al., 2007).

345 The influence of road networks on deforestation is associated to population migration and various socio-economic events. Large populations moved to Hainan Island, since it is area rich in natural resources (Yan, 2008). After the foundation of People's Republic of China in 1949, the economy became a key element in the national strategic plan. Both agriculture and forest farming developed rapidly, and large agricultural populations migrated to Hainan Island under the conduct of the national government. In the 1960s and 1970s, the 'sent-down youth' movement influenced the social activity and increased migration to Hainan. In the 1950s-1970s, roads were constructed for accessing land and timber resources and thus, the main road and secondary road network was markedly associated to natural forest deforestation (Table 2). In 1988, Hainan Island was established as a provincial agency and Economic Development Zone, leading to another population migration event, mainly of urban population. In the 1970s-1990s, roads were built for accessing land resources and linking major cities and towns; thus, the main road network had a stronger influence on deforestation than the secondary road network (Table 2). In the early 1990s, the industrial structure of Hainan Island was transformed and upgraded. The tertiary industry, especially tourism, became the core of economic development, changing the functions of road construction. Additionally, the Hainan Provincial Government established a natural forest logging ban in 1994 in response to the sharp decline in NFC (Standing Committee 
362 of Hainan Provincial People 's Congress, 1993). Consequently, the association between the road

363 network and deforestation weakened in 1990s-2010s (Table 2).

364 Deforestation was more affected by the main road network than the secondary road network

365 in the four assessed time periods (Table 2). Population was the most important factor affecting

366 NFC on Hainan (Zhang, Uusivuori \& Kuuluvainen, 2000; Lin \& Zhang, 2001). The main road

367 network of Hainan Island includes expressways, highways, and simply-built highways built or

368 funded by the national or provincial governments for geopolitical purposes, especially for

369 connecting major cities. The secondary road network includes cart roads and rural roads built or

370 funded by the city and county governments for supporting local livelihoods, connecting

371 communities, and accessing land and other natural resources. The construction of main roads

372 improves the connectivity of major cities, supports urbanisation (Perz et al., 2008), and thus,

373 highly increases deforestation. The construction of secondary roads also promotes deforestation,

374 but in a smaller scale than that of main roads (Fig. S2).

Implications for natural forest conservation and management

Our study provided significant information for natural forest conservation and management.

At a global scale, ecosystems decline and become fragmented (Saunders, Hobbs \& Margules,

1991; Fischer \& Lindenmayer, 2007), and thus, the small natural forest patches represent large elements of tropical natural forest (Tulloch et al., 2016). Theoretical and experimental studies have highlighted the importance of conserving large contiguous natural forest patches for maintaining biodiversity (Bender, Contreras \& Fahrig, 1998; Mortelliti et al., 2014).

Consequently, conservation actions have mainly focused on preserving large contiguous forest 
patches and not relatively small fragmented forest patches (Ovaskainen, 2002; Tulloch et al.,

384 2016). Small fragmented forest patches contribute to short-term and long-term indigenous

385 species persistence; enhance the biodiversity in human-dominated fragmented landscapes

386 (Turner \& Corlett, 1996); positively affect the diversity of forest bird and mammal species, forest

387 plant species, and migratory animals as well as the persistence of meta-populations (Laurance,

388 1994; Warkentin, Greenberg \& Salgado Ortiz, 1995; Jacquemyn, Jan Butaye \& Hermy, 2001);

389 act as refuges for plant and animal species; and help conservationists to launch a final attempt to

390 rescue endangered species that may serve as sources of natural forest reconstruction (Turner \&

391 Corlett, 1996). In Hainan, small natural forest patches are formed from the fragmentation of

392 larger contiguous natural forest patches. Those small natural forest patches are isolated and

393 always have an area less than 10 ha in Hainan. Those small natural forest patches are always

394 located at the edge of large contiguous natural forest in the mountainous region or around the

395 villages in the flat region, and provide important ecosystem services for local residents. For

396 example, the "Geomantic forest" in Wenchang and Qionghai counties is an example of small

397 natural forest patches- with typical tropical forest structure, but high plant diversity (Yang \& Wu,

398 2002), distributed in the Lingnan region that includes the modern Chinese provinces of Jiangxi,

399 Hunan, Guangdong, Guangxi, and Hainan. The Geomantic forest is related to the Fengshui

400 Theory, which includes historical and cultural features of ecological significance, and provides

401 important ecosystem services such as water and soil conservation as well as protection against

402 severe weather events (Cheng, He \& Liu, 2009). Due to this forest, the NFC of Wenchang

403 county increased from the 1950 s to the 2010s (Fig. 5). Thus, the protection of small natural 
404 forest patches is important, and long-term data need to be used for developing effective 405 management with specific conservation objectives. Regions with low NFC tend to be more 406 vulnerable in natural forest loss (Fig. 5). The natural forest loss and fragmentation patterns are 407 dynamic on Hainan (Fig. 6). Our results showed that the spatial and temporal change patterns of 408 NFC could be accurately assessed using historical data (Newman, McLaren \& Wilson, 2014). 409 Thus, conservationists and decision-makers need to evaluate natural forest changes and develop 410 effective management actions (Margules \& Pressey, 2000). On Hainan Island, regions with low 411 NFC, but high ecological value (Yangshan region in Haikou city; the Geomantic forest in 412 Wenchang city; Fig. 3) located in flat areas that are well developed and have high population 413 density, are more vulnerable than natural forest within the nature reserves. Thus, conservation 414 frameworks and forest restoration projects are needed to preserve or recover the natural forest.

415 The NFC in the mountainous region increased in the past 60 years; however, regions with

high NFC are vulnerable to fragmentation due to the expansion of the road network in some remote regions in the mountains (Fig. S2). The south-central mountainous region of Hainan

Island is a biodiversity hotspot (Myers et al., 2000) and thus, a priority area for conservation in

China (Ministry of Environmental Protection of the People 's Republic of China, 2011).

Monitoring the natural forest in using remote sensing and drones could help in protecting the natural forest and predict any future changes (Paneque-Gálvez et al., 2014).

CONCLUSIONS

This study used historical data to reconstruct NFC maps in order to better understand the 
425 spatial and temporal change patterns. The road network was identified as an important factor of 426 forest loss and fragmentation of tropical forests. Although the exact distribution of natural forest 427 was not depicted, we found that the dominant fragmented pattern of Hainan Island natural forest 428 is radial and dendritic.

429 Our study showed that: (1) low NFC corresponds to a high rate of NFC decrease as well as highly dynamic spatial and temporal change patterns of NFC; (2) the road network significantly affected NFC, whereas topography affected deforestation by influencing the road network construction pattern; and (3) the effect of road network on NFC was related to population migration and socio-economic events, and the main road network had a stronger relation to deforestation than the secondary road network.

Deforestation and fragmentation still occur in Hainan, and public concern remains

pronounced in recent years. Thus, it is crucial to better understand implications of deforestation on biodiversity conservation, as well as the driving forces of deforestation. Conservation efforts must focus on small natural forest patches using new technologies (e.g. remote sensing and drones) that will improve monitoring and data collection.

440 Although our model was incomplete, since it only included topography, climate and road network data, it revealed the spatial and temporal change patterns of NFC on Hainan Island.

442 Future modelling studies need to build an improved model, combining historical, natural, and 443 socio-economic factors that will help to better understand the underlying mechanisms of NFC 444 change patterns. 


\section{Acknowledgements}

446 We thank the Forestry Department of Hainan Province, the Administration Bureau of

447 Animal and Plant Protection of Hainan Province, and the staff of Nature Reserves for the

448 provided data and technical support. We are also grateful to the anonymous referees for their

449 valuable comments that helped to improve our manuscript. 
450

451

452

453

454

455

456

457

458

459

460

461

462

463

464

465

466

467

468

469

470

\section{References}

Ahmed SE, Souza CM, Riberio J, Ewers RM. 2013. Temporal patterns of road network development in the Brazilian Amazon. Regional Environmental Change 13: 927-937. DOI: 10.1007/s10113-012-0397-z.

Arima EY, Walker RT, Perz SG, Caldas M. 2005. Loggers and forest fragmentation: behavioral models of road building in the amazon basin. Annals of the Association of American Geographers 95:525-541. DOI: 10.1111/j.1467-8306.2005.00473.x.

Arima EY, Walker RT, Sales M, Souza Jr C, Perz SG. 2008. The fragmentation of space in the amazon basin: emergent road networks. Photogrammetric Engineering and Remote Sensing 74:699-709. DOI: 10.14358/PERS.74.6.699.

Arima EY, Walker RT, Perz S, Jr. CS. 2016. Explaining the fragmentation in the Brazilian Amazonian forest. Journal of Land Use Science 11:257-277. DOI: 10.1080/1747423X.2015.1027797.

Arima EY. 2016. A spatial probit econometric model of land change: the case of infrastructure development in western Amazonia, Peru. PloS One 11: e0152058. DOI: 10.1371/journal.pone.0152058.

Bender DJ, Contreras TA, Fahrig L. 1998. Habitat loss and population decline: a meta-analysis of the patch size effect. Ecology 79: 517-533. DOI: 10.1890/00129658(1998)079[0517:HLAPDA]2.0.CO;2.

Breiman L. 2001. Random forest. Machine Learning 45: 5-32. DOI: 10.1023/A:1010933404324.

Brook BWC, Bradshaw CJA, Koh LP, Sodhi NS. 2006. Momentum drives the crash: mass 
extinction in the tropics. Biotropica 38: 302-305. DOI: 10.1111/j.1744-7429.2006.00141.x.

472

473

474

475

476

477

478

479

480

481

482

483

484

485

486

487

488

489

490

491

Cai X, Wu Z, Cheng J. 2013. Using kernel density estimation to assess the spatial pattern of road density and its impact on landscape fragmentation. International Journal Geographical Information Science 27: 222-230. DOI: 10.1080/13658816.2012.663918.

Chen Z. 1948. Development of Hainan Island resources. Nanjing: Zhengzhong Press. (In Chinese)

Cheng J, He F, Liu Y. 2009. Progress of the research on Geomantic forest of Lingnan villages. Chinese landscape architecture 25: 93-96. (in Chinese with English abstract)

Cohen Y, Sharon R, Sokolsky T, Zahavi T. 2011. Modified hot-spot analysis for spatio-temporal analysis: a case study of the leaf-roll virus expansion in vineyards. Spatial 2-Spatial Data Methods for Environmental and Ecological Processes, At Foggia, Italy. Available at: https://aisberg.unibg.it/retrieve/handle/10446/25273/4012/40.pdf. (Accessed 25 February 2017)

Culter DR, Edwards TCJ, Beard KH, Cutler A, Hess KT. 2007. Random forest for classification in ecology. Ecology 88: 2783-2792. DOI: 10.1890/07-0539.1.

Defries R, Hansen A, Newton AC, Hansen MC. 2005. Increasing isolation of protected areas in tropical forests over the past twenty years. Ecological Applications 15, 19-26. DOI: 10.1890/03-5258.

Dirzo R, Young HS, Galetti M, Ceballos G, Isaac NJ, Collen B. 2014. Defaunation in the Anthropocene. Science 345: 401-406. DOI: 10.1126/science.1251817.

Ellis EC, Kaplan JO, Fuller DQ, Vavrus S, Klein GK, Verburg, PH. 2013. Used planet: a global 
ESRI, 2008. ArcGIS 9.3. Environmental Systems Research Institute Inc.: Redlands, CA.

495

496

497

498

499

500

501

502

503

504

505

506

507

508

509

510

511

512

Fearnside PM. 2008. The roles and movements of actors in the deforestation of Brazilian Amazonia. Ecology and Society 13, 23. Available at: http://www.ecologyandsociety.org/vol13/iss1/art23/.

Fischer J, Lindenmayer DB. 2007. Landscape modification and habitat fragmentation: a synthesis. Global Ecology and Biogeography 16: 265-280. DOI: 10.1111/j.14668238.2007.00287.x.

Francisco-Ortega J, Wang ZS, Wang FG, Xing FW, Liu H, Xu H, Xu WX, Luo YB, Song XQ, Gale S, Boufford DE, Maunder M, An SQ. 2010. Seed plant endemism on Hainan Island: a framework for conservation actions. The Botanical Review 76: 346-376. DOI: $10.1007 / \mathrm{s} 12229-010-9055-7$.

Freitas SR, Hawbaker TJ, Metzger JP. 2010. Effects of roads, topography, and land use on forest cover dynamics in the Brazilian Atlantic Forest. Forest Ecology and Management 259: 410417. DOI: 10.1016/j.foreco.2009.10.036.

Gaveau DL, Wich S, Epting J, Juhn D, Kanninen M, Leader-Williams N. 2009. The future of forests and orangutans (Pongo abelii) in Sumatra: predicting impacts of oil palm plantations, road construction, and mechanisms for reducing carbon emissions from deforestation. Environmental Research Letters 4: 034013. DOI: 10.1088/1748-9326/4/3/034013. 
Getis A, Ord JK. 1996. Local spatial statistics: an overview. In Longley P, Batty M, ed. Spatial 294.

Hu X, Wu Z, Wu C, Ye L, Lan C, Tang K, Xu L, Qiu R. 2016. Effects of road network on 
534

535

536

537

538

539

540

541

542

543

544

545

546

547

548

549

550

551

552

553

554

diversiform forest cover changes in the highest coverage region in China: An analysis of sampling strategies. Science of The Total Environment 565: 28-39. DOI: 10.1016/j.scitotenv.2016.04.009.

Iverson LR, Prasad AM, Matthews SN, Peters M. 2008. Estimating potential habitat for 134 eastern us tree species under six climate scenarios. Forest Ecology and Management 254: 390-406. DOI: 10.1016/j.foreco.2007.07.023.

Jacquemyn H, Jan Butaye J, Hermy M. 2001. Forest plant species richness in small, fragmented mixed deciduous forest patches: the role of area, time and dispersal limitation. Journal of Biogeography 28: 801-812. DOI: 10.1046/j.1365-2699.2001.00590.x.

Kuhn M. 2016. caret: Classification and Regression Training. R package version 6.0-73. Available at: https://CRAN.R-project.org/package=caret. (accessed 6 March 2017)

Lambin EF, Geist HJ. 2006. Land-Use and Land-Cover Change. Berlin: Springer.

Lambin EF, Geist HJ, Lepers E. 2003. Dynamics of land-used and land-cover change in tropical regions. Annual Review of Environment and Resources 28: 205-241. DOI: 10.1146/annurev.energy.28.050302.105459.

Laurance WF, Ferreira LV, Rankin-de Merona JM, Laurance SG. 1998. Rain forest fragmentation and the dynamics of Amazonian tree communities. Ecology 79: 2032-2040. DOI: 10.1890/0012-9658(1998)079[2032:RFFATD]2.0.CO;2.

Laurance WF. 1994. Rainforest fragmentation and the structure of small mammal communities in tropical Queensland. Biological Conservation 69: 23-32. DOI: 10.1016/00063207(94)90325-5. 
555 Laurance WF, Goosem M, Laurance SGW. 2009. Impacts of roads and linear clearings on 556 tropical forests. Trends in Ecology and Evolution 24: 659-669. DOI: 10.1016/j.tree.2009.06.009.

558

559

560

561

562

Lewis SL, Maslin MA. 2015. Defining the Anthropocene. Nature 519: 171-80. DOI: 10.1038/nature14258.

Li M, De Pinto A, Ulimwengu JM, You L, Robertson RD. 2014. Impacts of Road Expansion on Deforestation and Biological Carbon Loss in the Democratic Republic of Congo. Environmental and Resource Economics 60: 433-469. DOI: 10.1007/s10640-014-9775-y.

Li X. 2013. Using "random forest" for classification and regression. Chinese journal of applied entomology 50:1190-1197. DOI: 10.7679/j.issn.2095-1353.2013.163. (in Chinese with English abstract)

Liaw A, Wiener M. 2002. Classification and Regression by random Forest. $R$ News 2: 18-22. Available online: https://cran.r-project.org/doc/Rnews/ (accessed on 3 Jan. 2016)

Lin M, Zhang Y. 2001. Dynamic change of tropical forest in Hainan Island. Geographical research 20: 703-712. DOI: 10.11821/yj2001060008. (in Chinese with English abstract)

Lin S, Xu Y, He J, Ma G, Jiang H. 2015. Study on Forest Ecosystem. In: Xing Q, Shi J, Lin Z, ed. Hainan provincial biodiversity conservation strategy and action plan (2014-2030). Beijing: Sciences Press (in Chinese).

Liu M, Tian H. 2010. China's land cover and land use change from 1700 to 2005: Estimations from high resolution satellite data and historical archives. Global Biogeochemical Cycles 24: 
576

577

578

579

580

581

582

583

584

585

586

587

588

589

590

591

592

593

594

595

596

MacDicken KG. 2015. Global Forest Resources Assessment 2015: What, why and how? Forest Ecology and Management 352: 3-8. DOI: 10.1016/j.foreco.2015.02.006.

Margules CR, Pressey RL. 2000. Systematic conservation planning. Nature 405: 243-253. DOI: $10.1038 / 35012251$

Mertens B, Lambin EF. 1997. Spatial modelling of deforestation in southern Cameroon: Spatial disaggregation of diverse deforestation processes. Applied Geography 17: 143-162. DOI:10.1016/S0143-6228(97)00032-5.

Miao L, Zhu F, He B, Ferrat M, Liu Q, Cao X, Cui X. 2013. Synthesis of China's land use in the past 300 years. Global and Planetary Change 100: 224-233. DOI: 10.1016/j.gloplacha.2012.10.021.

Millington JDA, Perry GLW, Romero-Calcerrada R. 2007. Regression techniques for examining land use/cover change: a case study of a Mediterranean landscape. Ecosystems 10: 562-578. DOI: $10.1007 / \mathrm{s} 10021-007-9020-4$.

Ministry of Environmental Protection of the People 's Republic of China. 2013. China national biodiversity conservation strategy and action plan (2011-2030). Beijing: China Environmental Science Press. (in Chinese with English version)

Mitchell A. 2005. The ESRI Guide to GIS Analysis, Volume 2: Spatial Measurements and Statistics. Hongkong: Esri Press.

Mortelliti A, Sozio G, Driscoll DA, Bani L, Boitani L, Lindenmayer DB. 2014. Population and individual-scale responses to patch size, isolation and quality in the hazel dormouse. Ecosphere 5: 1-21. DOI: 10.1890/ES14-00115.1. 
597

598

599

600

601

602

603

604

605

606

607

608

609

610

611

612

613

614

615

616

617

Myers N, Mittermeier RA, Mittermeier C., da Fonseca GAB, Kent J, 2000. Biodiversity hotspots for conservation priorities. Nature 403: 853-858. DOI: 10.1038/35002501.

Newman ME, McLaren KP, Wilson BS. 2014. Assessing deforestation and fragmentation in a tropical moist forest over 68 years; the impact of roads and legal protection in the Cockpit Country, Jamaica. Forest Ecology and Management 315: 138-152. DOI: 10.1016/j.foreco.2013.12.033.

Ovaskainen O. 2002. Long-term persistence of species and the SLOSS problem. Journal of Theoretical Biology 218: 419-433. DOI: 10.1006/jtbi.2002.3089.

Page SE, Rieley JO, Banks CJ. 2011. Global and regional importance of the tropical peatland carbon pool. Global Change Biology 17: 798-818. DOI: 10.1111/j.1365-2486.2010.02279.x.

Paneque-Gálvez J, McCall MK, Napoletano BM, Wich SA, Koh LP. 2014 Small drones for community-based forest monitoring: an assessment of their feasibility and potential in tropical areas. Forests 5: 1481-1507. DOI: 10.3390/f5061481.

Perz SG, Overdevest C, Caldas MM, Walker RT, Arima EY. 2007. Unofficial road building in the brazilian amazon: dilemmas and models for road governance. Environmental Conservation 34: 112-121. DOI: 10.1017/S0376892907003827.

Perz SG, Walker R, Caldas M, Arima E, Souza C. 2008. Road networks and forest fragmentation in the Amazon: explanations for local differences with implications for conservation and development. Journal of Latin American Geography 7: 85-104. DOI: 10.1353/lag.0.0004.

Pimm SL.1998. Ecology-the forest fragment classic. Nature 393: 23-24. DOI: 10.1038/29892.

Pongratz J, Reick C, Raddatz T, Claussen M. 2008. A reconstruction of global agricultural areas 
618

619

620

621

622

623

624

625

626

627

628

629

630

631

632

633

634

635

636

637

638

and land cover for the last millennium. Global Biogeochemical Cycles 22: GB3018. DOI: 10.1029/2007GB003153.

R Development Core Team. 2016. R: a language and environment for statistical computing. Version 3.2.3. Vienna: R Foundation for Statistical Computing. Available at: http://www.Rproject.org/.

Romijn E, Lantican CB, Herold M, Lindquist E, Ochieng R, Wijaya A, Murdiyarso D, Verchot L. 2015. Assessing change in national forest monitoring capacities of 99 tropical countries. Forest Ecology and Management 352: 109-123. DOI: 10.1016/j.foreco.2015.06.003.

Saunders DA, Hobbs RJ, Margules CR. 1991. Biological consequences of ecosystem fragmentation: a review. Conservation Biology 5: 18-32. DOI: 10.1111/j.15231739.1991.tb00384.x.

Scott L, Warmerdam N. 2005. Extend Crime Analysis with ArcGIS Spatial Statistics Tools. Available at: http://www.esri.com/news/arcuser/0405/ss_crimestats 1 of $2 . h t m l$. (accessed 6 March 2017)

Selva N, Kreft S, Kati V, Schluck M, Jonsson BG, Mihok B, Okarma H, Ibisch PL. 2011. Roadless and low-traffic areas as conservation targets in Europe. Environmental Management 48: 865-877. DOI: 10.1007/s00267-011-9751-z.

State Forestry Administration of the People's Republic of China (SFA PRC). 2004. The Technical Regulations of National Forest Inventory. Available at http://211.167.243.162:8085/8/workdyfront/fileSingle?lm=dcgz\&mfile.GUID=309CE283D 9D240AB915B023020A69C0B (accessed 5 October 2016). 
639 Soares-Filho BS, Nepstad DC, Curran LM, Cerqueira GC, Garcia RA, Ramos CA, Voll E, 640 McDonald A, Lefebvre P, Schlesinger P. 2006. Modelling conservation in the amazon basin. $641 \quad$ Nature 440: 520-523. DOI: 10.1038/nature04389.

642 Sodhi NS, Koh LP, Brook BW, Ng PK. 2006. Southeast Asian biodiversity: an impending 643 disaster. Trends in Ecology and Evolution 19: 654-660. DOI: 10.1016/j.tree.2004.09.006.

644 Standing Committee of Hainan Provincial People 's Congress. 1993. Statute on forest protection 645 and management in Hainan Province. Available at: http://www.hizw.gov.cn/data/news/2015/05/43511/. (accessed 20 February 2017)

647

648

649

650

651

652

653

654

655

656

657

658

659
Fund

Wildlife

http://awsassets.wwf.org.au/downloads/f1012_bushland_at_risk_of_renewed_clearing_in_q ueensland_9may13.pdf (accessed 5 October 2016).

Teixeira AMG, Soares-Filho BS, Freitas SR, Metzger JP. 2009. Modeling landscape dynamics in an Atlantic Rainforest region: implications for conservation. Forest Ecology and Management 257: 1219-1230. DOI: 10.1016/j.foreco.2008.10.011.

Torgo L. 2011. Data Mining with R: learning with case studies. Boca Raton: CRC Press. Available at: http://www.dcc.fc.up.pt/ ltorgo/DataMiningWithR. (accessed 6 March 2017) 
660 Tulloch AI., Barne, MD, Ringma J, Fuller RA, Watson JEM. 2016. Understanding the 661 importance of small patches of habitat for conservation. Journal of Applied Ecology 53: 418-429. DOI: 10.1111/1365-2664.12547.

663

664

665

666

667

668

669

670

671

672

673

674

675

676

677

678

679

680

Turner IM, Corlett RT. 1996. The conservation value of small, isolated fragments of lowland tropical rain forest. Trends in Ecology and Evolution 11: 330-333. DOI: 10.1016/01695347(96)10046-X.

van der Ree R, Smith DJ, Grilo C. 2015. Handbook of Road Ecology. New Jersey: Wiley Blackwell.

Walker R, Arima E, Messina J, Soaresfilho B, Perz S, Vergara D, Sales M, Pereira R, Castro W. 2013. Modeling spatial decisions with graph theory: logging roads and forest fragmentation in the Brazilian Amazon. Ecological Applications 23: 239-254. DOI: 10.1890/11-1800.1.

Wang X, Li G, Hu W, Wu X, Zhang Y. 2014. Preliminary analysis of inductive factors and the influence mechanism of Diaoluo Mountain landslide. Journal of Natural Disasters 1: 144148 (in Chinese with English abstract). DOI: 10.13577/j.jnd.2014.0120.

Warkentin IG, Greenberg R, Salgado Ortiz J. 1995. Songbird use of gallery woodlands in recently cleared and older settled landscapes of the Selva Lacandona, Chiapas, Mexico. Conservation Biology 9: 1095-1106. DOI: 10.1046/j.1523-1739.1995.951095.x.

Wilkie D, Shaw E, Rotberg F, Morelli G, Auzel P. 2000. Roads, development, and conservation in the Congo basin. Conservation Biology 14: 1614-1622. DOI: 10.1111/j.15231739.2000.99102.x.

Wood SN. 2011. Fast stable restricted maximum likelihood and marginal likelihood estimation 

73:3-36. DOI: 10.1111/j.1467-9868.2010.00749.x.

$683 \mathrm{Xu} \mathrm{Y,} \mathrm{Lin} \mathrm{S,} \mathrm{He} \mathrm{J,} \mathrm{Xin} \mathrm{Y,} \mathrm{Zhang} \mathrm{L,} \mathrm{Jiang} \mathrm{H,} \mathrm{Li} \mathrm{Y.} \mathrm{2016.} \mathrm{Tropical} \mathrm{birds} \mathrm{are} \mathrm{declining} \mathrm{in} \mathrm{the}$ 684 Hainan Island of China. Biological Conservation (in press). DOI: 10.1016/j.biocon.2016.05.029.

Yan J. 2008. The study on evolutional history of Hainan Island's ecological environment. Beijing. Science Press. (in Chinese)

Yang X, Wu Q. 2002. Study on the characteristics of rural vegetation and the eco-environmental problems of agriculture development in Wenchang Changsa, Hainan. Nature science journal of Hainan university 20: 239-242. DOI: 1004-1729(2002)03-0239-04. (in Chinese with English abstract)

Zhang YQ, Uusivuori J, Kuuluvainen J. 2000. Econometric analysis of the causes of forest landuse changes in Hainan, China. Canadian Journal of Forest Research 30: 1913-1921. DOI: 10.1139/x00-123. 
Figure 1

Location and topography of Hainan Island, China.

JFL, Jianfengling Mountain; BWL, Bawangling Mountain; YGL, Yinggeling Mountain; WZS, Wuzhishan Mountain; DLS, Diaoluoshan Mountain.

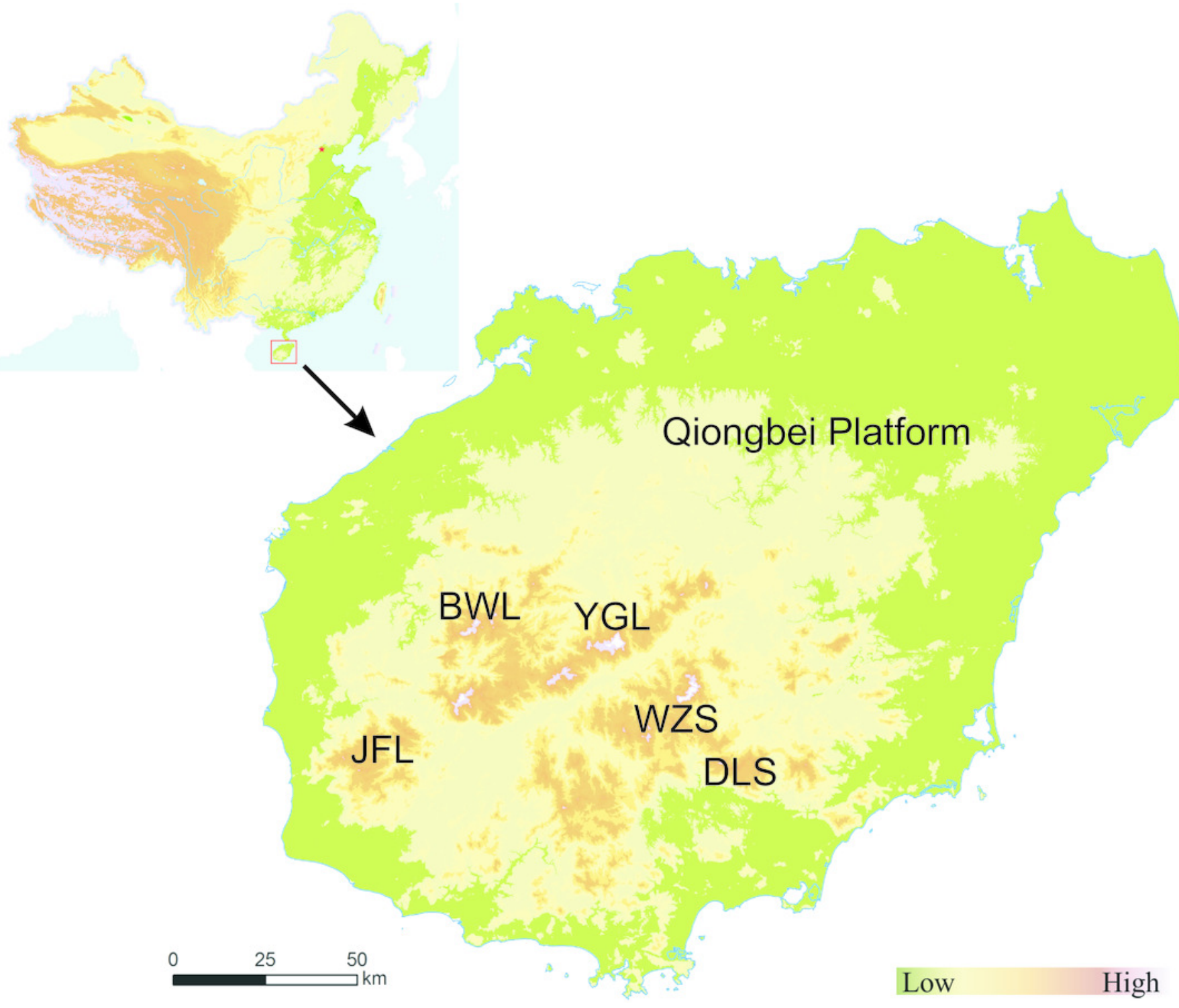


Figure 2

Flowchart showing the methodological sequence describing the input data, the modelling and validation approaches, and the generation of predictions.

\section{Response Data}

Data

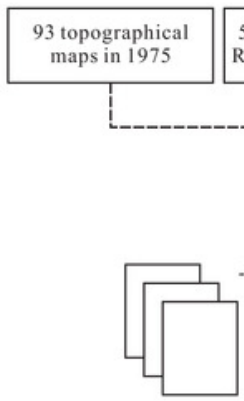

5th National Forest Resources Inventory

Resources Inventory

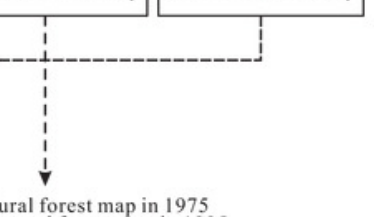

\section{Explanatory Data}
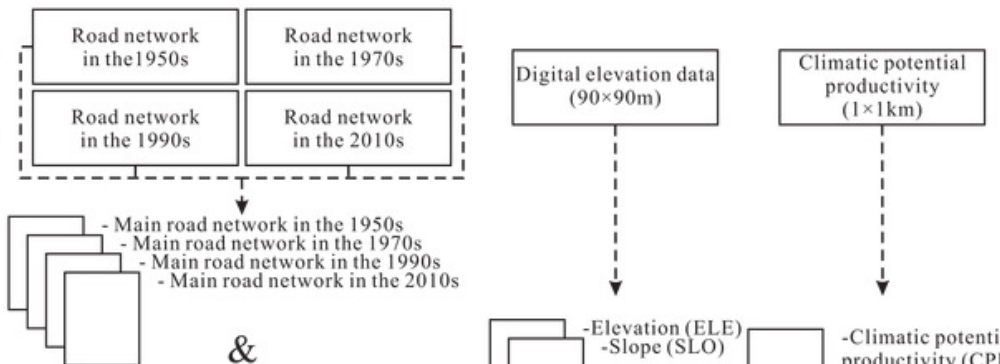

-Natural forest map in 2012

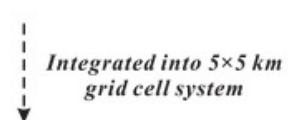

- Secondary road network in the $1950 \mathrm{~s}$

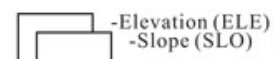

-Climatic potential productivity (CPP)

Modlling

Validation
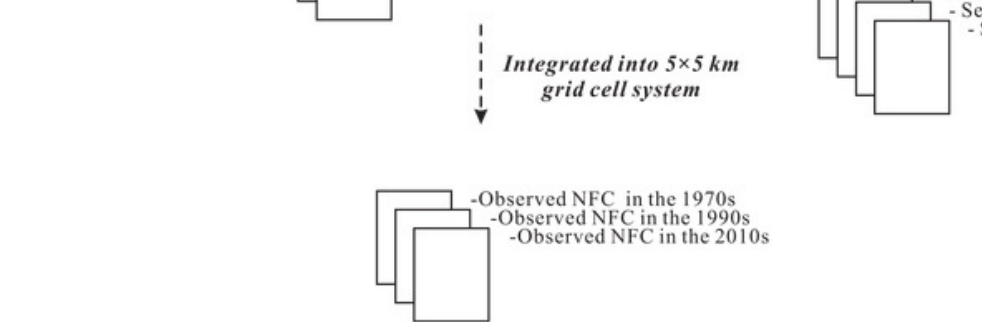

列
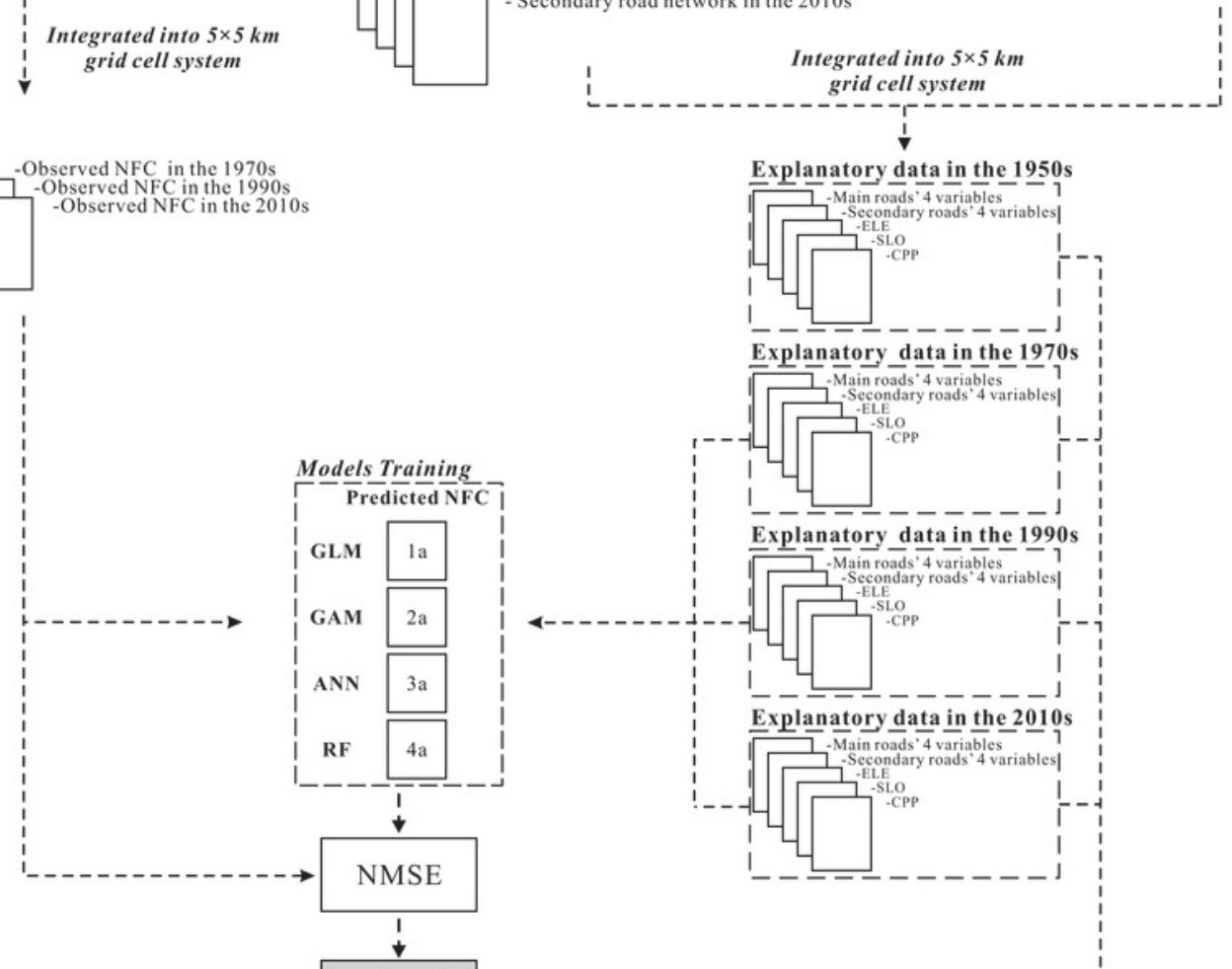

Yalidation

\section{Predictions}
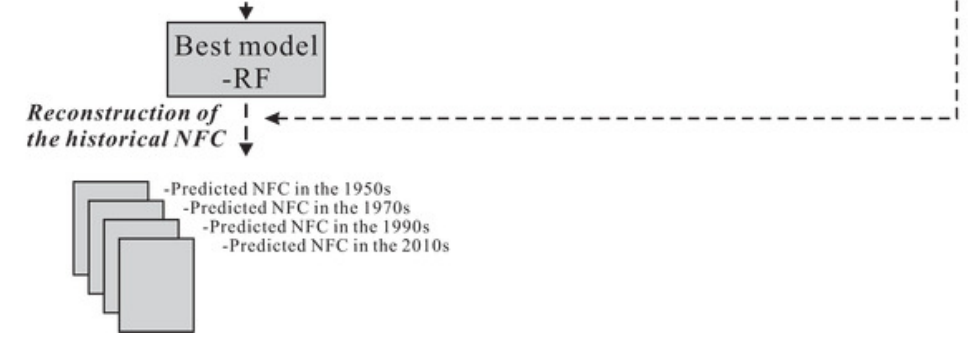
Figure 3

Distribution patterns and histogram statistics of natural forest cover (NFC) in the 1950s (A), the 1970s (B), the 1990s (C) and the 2010s (D) on Hainan Island.
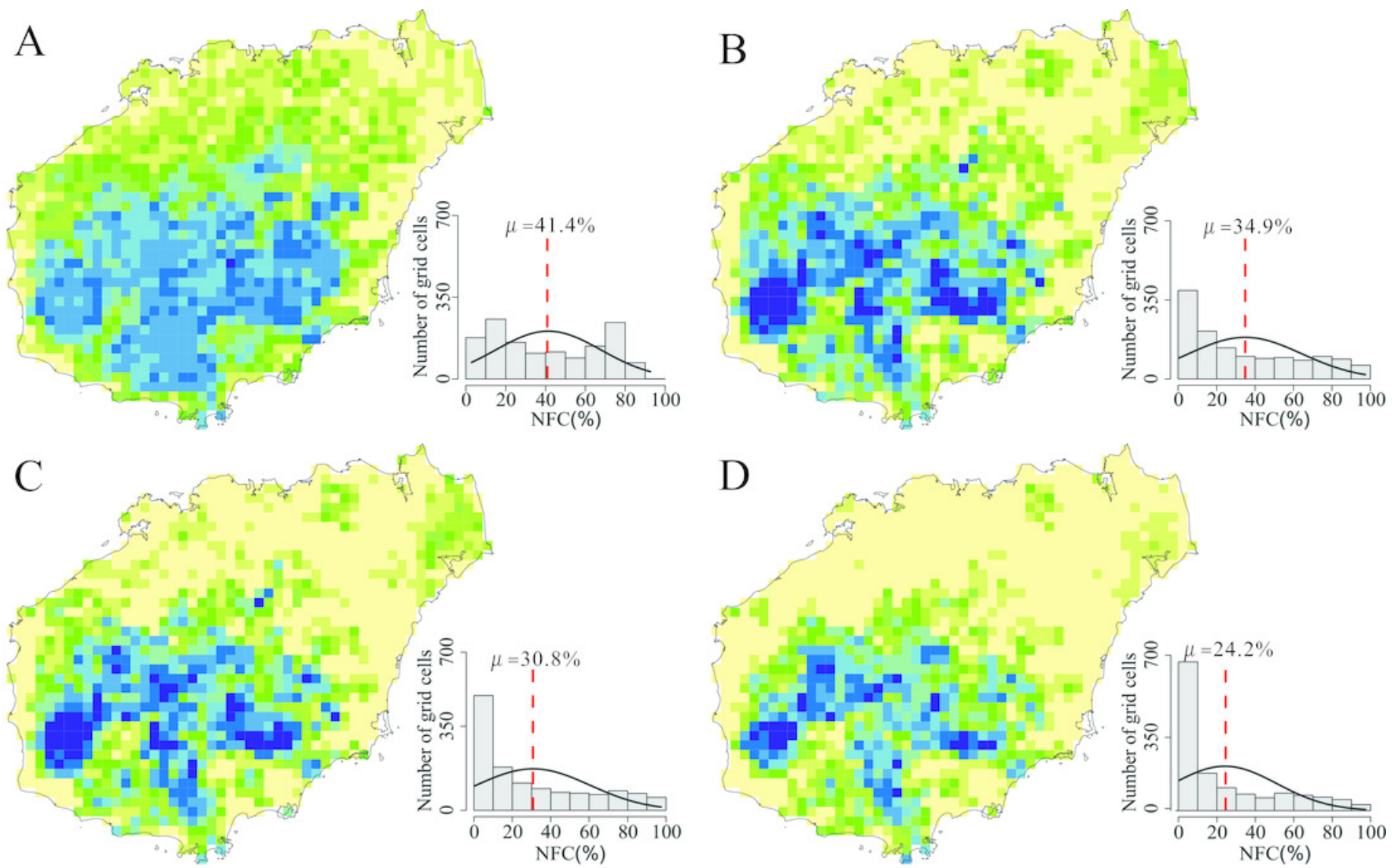

Natural Forest cover (NFC, \%)

$\leqslant 10$

$10.1-20$

$20.1-30$

$30.1-40$

$40.1-50$

$50.1-60$

$60.1-70$

$70.1-80$

$80.1-90$

$90.1-100$ 
Figure 4

Trend of total natural forest cover (NFC) from the 1950s to the 2010s on Hainan Island.

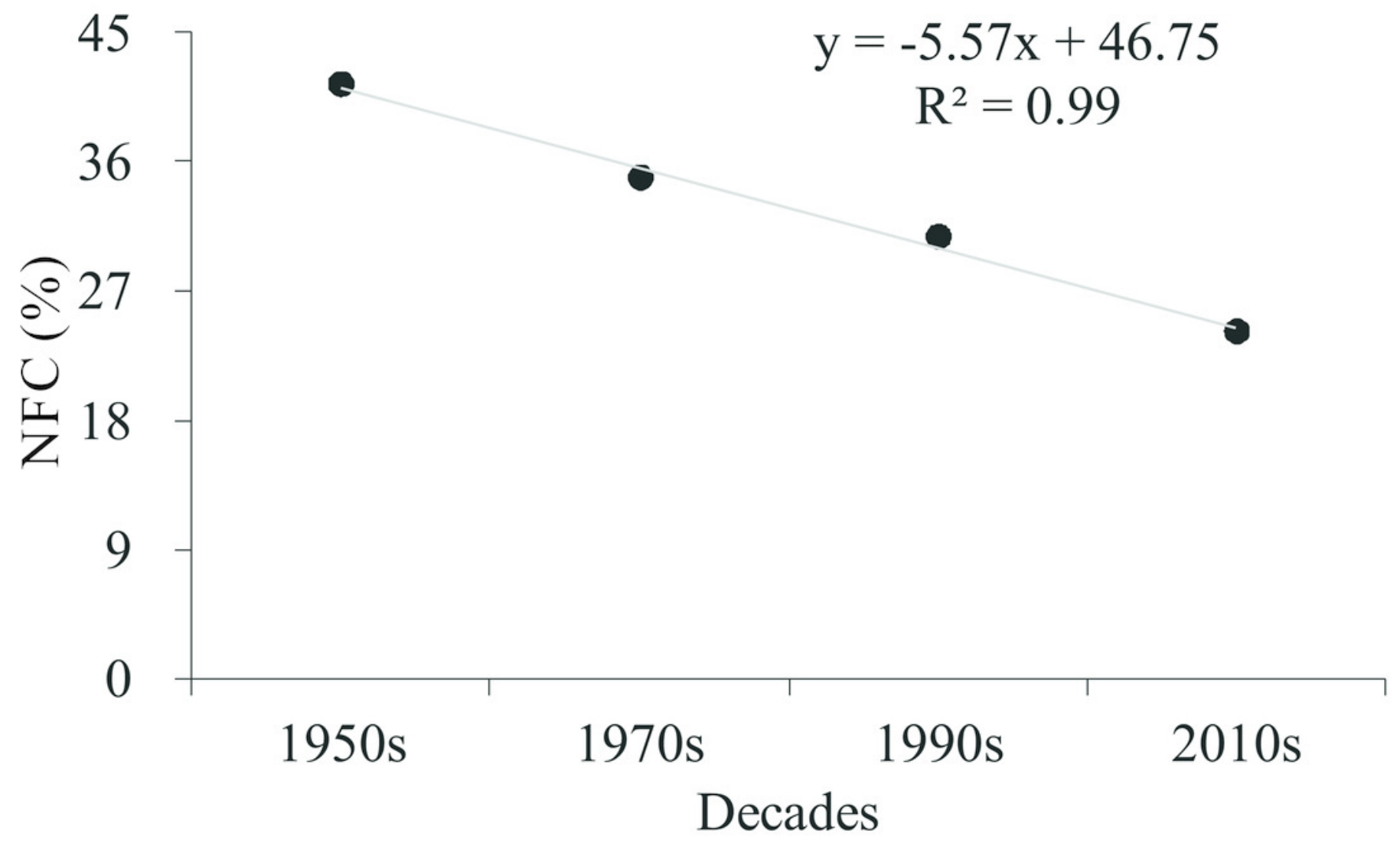


Figure 5

The site-specific relationships between NFC and its change rate (A), and the distribution pattern of change rate (B) from the 1950s to the 2010s.

Green represents high NFC $(\geq 60 \%)$ in the 1950 s and had NFC increased from the 1950 s to the 2010s; Red represents low NFC ( $\leq 20 \%)$ in the 1950s and had NFC decreased from the 1950 s to the 2010 s.
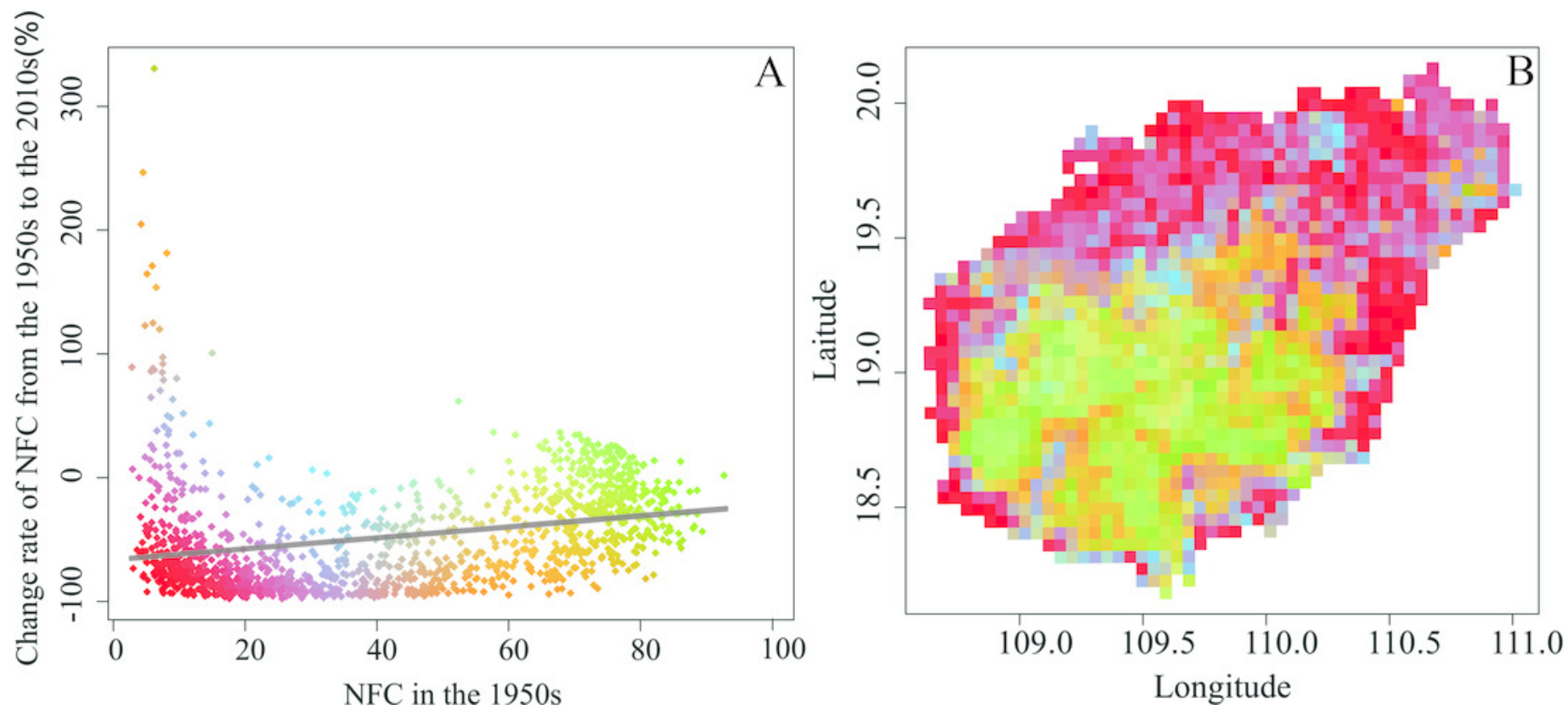
Figure 6

Hot-spots of natural forest cover (NFC) decrease and increase in four assessed periods: 1950s-2010s (A), 1950s-1970s (B), 1970s-1990s (C), and 1990s-2010s (D) on Hainan Island.
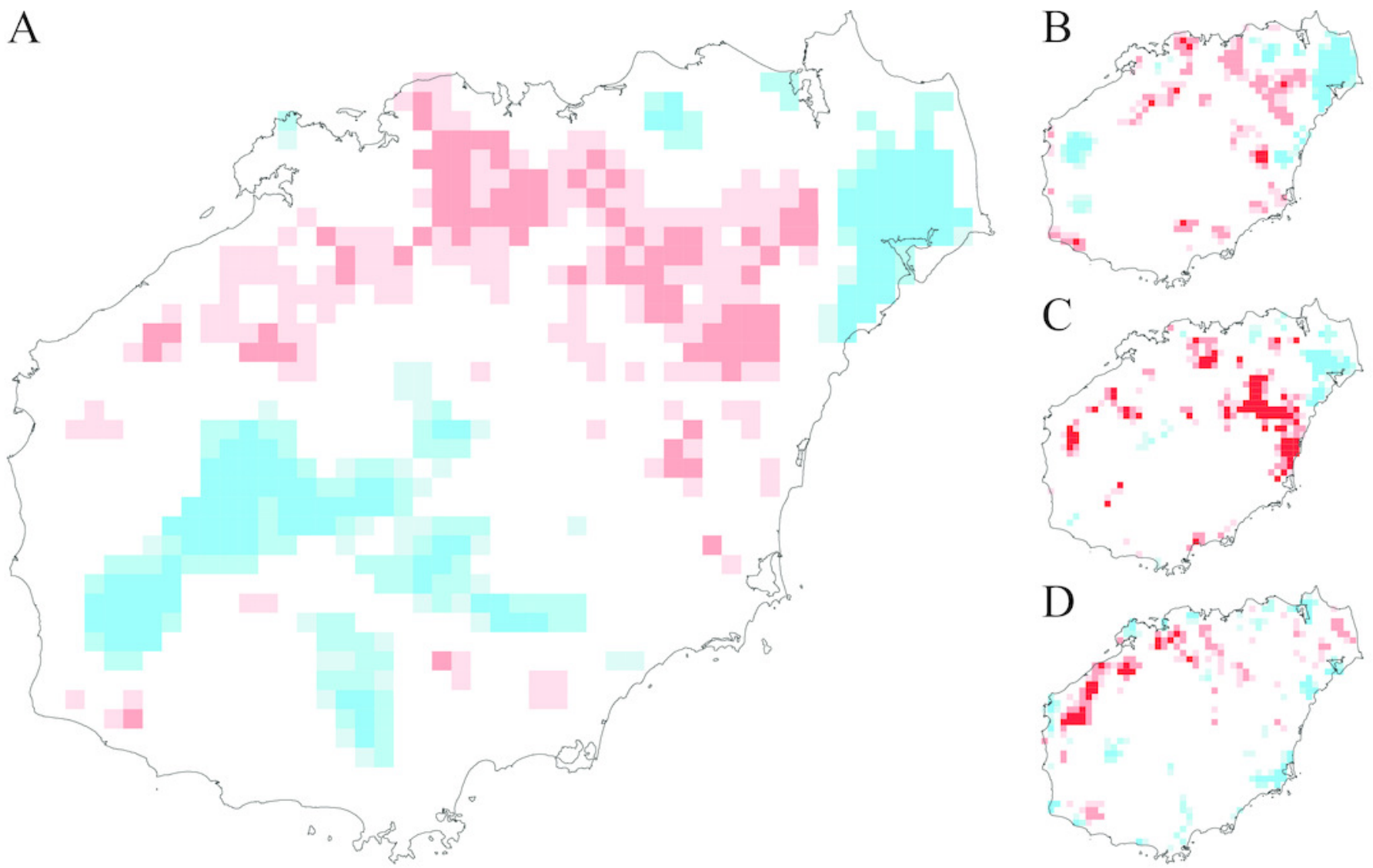

Reforestation Hot-spots (99\% confidence) Reforestation Hot-spots (95\% confidence) Reforestation Hot-spots (90\% confidence)
Deforestation Hot-spots (99\% confidence) Deforestation Hot-spots (95\% confidence) Deforestation Hot-spots (90\% confidence) 


\section{Table $\mathbf{1}$ (on next page)}

Changes in road-related variables of main and secondary roads from the 1950s to the 2010s on Hainan Island.

Data are the means and standard deviation of all grid cells. SRL, sum of road length $(\mathrm{km}$ $\left.\mathrm{km}^{-2}\right)$; DNR, distance from the grid cell centroid to the nearest road $(\mathrm{km})$; NON, number of nodes of road network (ea $\mathrm{km}^{-2}$ ); MND, mean number of roads connected by each node (ea $\left.\mathrm{km}^{-2}\right)$. 
$1 \quad$ Table 1

\begin{tabular}{llcccc}
\hline & & 1950s & 1970s & 1990s & 2010s \\
\hline \multirow{2}{*}{ SRL } & Main road & $0.11 \pm 0.17$ & $0.23 \pm 0.22$ & $0.27 \pm 0.24$ & $0.45 \pm 0.27$ \\
& Secondary road & $0.18 \pm 0.18$ & $0.36 \pm 0.23$ & $0.36 \pm 0.23$ & $0.36 \pm 0.23$ \\
\hline \multirow{2}{*}{ DNR } & Main road & $0.30 \pm 0.29$ & $0.09 \pm 0.08$ & $0.08 \pm 0.08$ & $0.04 \pm 0.04$ \\
& Secondary road & $0.11 \pm 0.11$ & $0.05 \pm 0.05$ & $0.05 \pm 0.04$ & $0.05 \pm 0.04$ \\
\hline \multirow{2}{*}{ NON } & Main road & $0.01 \pm 0.04$ & $0.09 \pm 0.20$ & $0.11 \pm 0.20$ & $0.20 \pm 0.23$ \\
& Secondary road & $0.03 \pm 0.06$ & $0.23 \pm 0.21$ & $0.23 \pm 0.21$ & $0.23 \pm 0.21$ \\
\hline \multirow{2}{*}{ MND } & Main road & $0.02 \pm 0.05$ & $0.04 \pm 0.04$ & $0.05 \pm 0.04$ & $0.07 \pm 0.04$ \\
& Secondary road & $0.03 \pm 0.05$ & $0.05 \pm 0.03$ & $0.05 \pm 0.03$ & $0.05 \pm 0.03$ \\
\hline
\end{tabular}

2 


\section{Table 2 (on next page)}

The explanatory power (Adjusted $\mathrm{R}^{2}, \%$ ) of the change of road-related indicators in a simple linear regression model.

SRL, sum of road length; DNR, distance from the grid cell centroid to the nearest road; NON, number of nodes of road network; MND, mean number of roads connected by each node. The $p$ value represents the significance level of the relationship between NFC change rate and change of road-related indicators. ${ }^{*}$, significant at $p<0.05 ;{ }^{* *}$, significant at $p<0.01 ;{ }^{* * *}$, significant at $p<0.001$. 
Table 2

\begin{tabular}{|c|c|c|c|c|c|c|c|c|c|}
\hline \multicolumn{2}{|c|}{ Change of road-related indicators } & \multicolumn{2}{|c|}{$\begin{array}{l}\text { Change of NFC in } \\
\text { the } 1950 \mathrm{~s}-2010 \mathrm{~s}\end{array}$} & \multicolumn{2}{|c|}{$\begin{array}{l}\text { Change of NFC } \\
\text { in the } 1950 \mathrm{~s}-1970 \mathrm{~s}\end{array}$} & \multicolumn{2}{|c|}{$\begin{array}{l}\text { Change of NFC } \\
\text { in the } 1970 \mathrm{~s}-1990 \mathrm{~s}\end{array}$} & \multicolumn{2}{|c|}{$\begin{array}{l}\text { Change of NFC } \\
\text { in the } 1990 \mathrm{~s}-2010 \mathrm{~s}\end{array}$} \\
\hline Type of road & Indicators & Adjusted $\mathrm{R}^{2}$ & $p$ value & Adjusted $\mathrm{R}^{2}$ & $p$ value & Adjusted $\mathrm{R}^{2}$ & $p$ value & Adjusted $\mathrm{R}^{2}$ & $p$ value \\
\hline \multirow{5}{*}{ Main road } & Change of SRL & 11.20 & $<0.001^{* * *}$ & 14.22 & $<0.001^{* * *}$ & 20.73 & $<0.001^{* * *}$ & 4.89 & $<0.001^{* * *}$ \\
\hline & Change of DNR & 11.07 & $<0.001^{* * *}$ & 0.27 & $0.031^{*}$ & 5.97 & $<0.001^{* * *}$ & 0.45 & $0.007^{* * *}$ \\
\hline & Change of NON & 4.83 & $<0.001^{* * *}$ & 4.37 & $<0.001^{* * *}$ & 19.03 & $<0.001^{* * *}$ & 1.76 & $<0.001^{* * *}$ \\
\hline & Change of MND & 5.59 & $<0.001^{* * *}$ & 8.31 & $<0.001^{* * *}$ & 7.35 & $<0.001^{* * *}$ & 2.30 & $<0.001^{* * *}$ \\
\hline & Overall & 23.40 & $<0.001^{* * *}$ & 17.67 & $<0.001^{* * *}$ & 25.20 & $<0.001^{* * *}$ & 5.10 & $<0.001^{* * *}$ \\
\hline \multirow{5}{*}{ Secondary road } & Change of SRL & 0.32 & $0.021^{*}$ & 0.14 & 0.089 & 0.36 & $0.015^{*}$ & $<0.01$ & 0.613 \\
\hline & Change of DNR & 7.14 & $<0.001^{* * *}$ & 5.26 & $<0.001^{* * *}$ & $<0.01$ & 0.801 & 0.32 & $0.021 *$ \\
\hline & Change of NON & 5.11 & $<0.001^{* * *}$ & 2.26 & $<0.001^{* * *}$ & $<0.01$ & 0.932 & 0.01 & 0.422 \\
\hline & Change of MND & 0.22 & $0.045^{*}$ & 1.11 & $<0.001^{* * *}$ & $<0.01$ & 0.505 & 0.01 & 0.605 \\
\hline & Overall & 13.3 & $<0.001^{* * *}$ & 8.99 & $<0.001^{* * *}$ & 0.31 & 0.085 & 0.12 & 0.228 \\
\hline \multicolumn{2}{|c|}{ Main road \& Secondary road } & 30.7 & $<0.001^{* * *}$ & 22.5 & $<0.001^{* * *}$ & 26.0 & $<0.001^{* * *}$ & 5.4 & $<0.001^{* * *}$ \\
\hline
\end{tabular}

2 